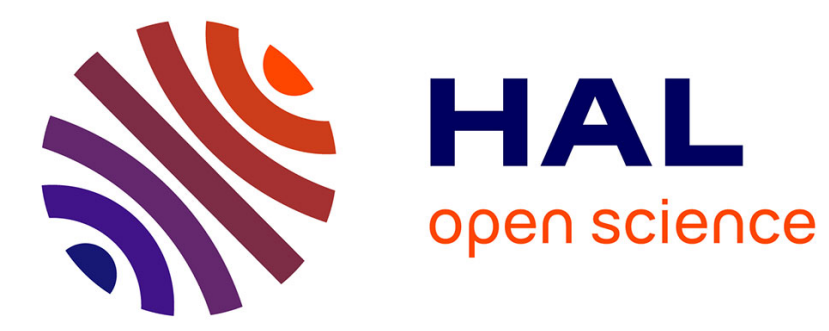

\title{
Small firms and the growth stage: can entrepreneurship education programmes be supportive?
}

\author{
Sylvain Bureau, Elisa Salvador, Jacqueline Fendt
}

\section{To cite this version:}

Sylvain Bureau, Elisa Salvador, Jacqueline Fendt. Small firms and the growth stage: can entrepreneurship education programmes be supportive?. Industry and Higher Education, 2012, 26 (2), pp.79-100. hal-02530098

\section{HAL Id: hal-02530098 \\ https://hal.science/hal-02530098}

Submitted on 2 Apr 2020

HAL is a multi-disciplinary open access archive for the deposit and dissemination of scientific research documents, whether they are published or not. The documents may come from teaching and research institutions in France or abroad, or from public or private research centers.
L'archive ouverte pluridisciplinaire HAL, est destinée au dépôt et à la diffusion de documents scientifiques de niveau recherche, publiés ou non, émanant des établissements d'enseignement et de recherche français ou étrangers, des laboratoires publics ou privés. 


\title{
This article has been accepted for publication by the Journal Industry and Higher Education
}

It can be cited as follows:

Bureau S., Salvador E., Fendt J. (2012) "Small firms and the growth stage: can entrepreneurship education programmes be supportive?", Industry and Higher Education, vol. 26 (2): 79-100.

\section{Small firms and the growth stage: can entrepreneurship education}

\author{
programmes be supportive?
}

Bureau* S., Salvador** E., Fendt $^{* * *}$ J.

\begin{abstract}
Entrepreneurship education is booming but focuses on nascent entrepreneurs and company creation. Yet a major challenge in small business entrepreneurship is growth. We first position growth and its barriers in small firms, and current theory and practice of entrepreneurship education. From this, we draw prerequisites and drivers for small business, growth-related entrepreneurship training. Grounded in this, we share a pedagogic experiment focused on growth, for a mixed audience of small firm entrepreneurs and graduate students enrolled in an entrepreneurship major within a business school. We frame the experiment as an integrated process model. We suggest that such programs could develop in three main directions: i) change the business school, to become less individual-centered, more open and value creating for its students and outside, ii) strongly and regularly involve entrepreneurship students in business realities beyond the start-up level and iii) make systematic and sophisticated use of the Internet for growth-enhancement through e-learning and community-building.
\end{abstract}

Keywords: entrepreneurship education; entrepreneurial ventures; entrepreneurial growth; action learning; business schools, community management.

A first draft of this paper has been presented at the International Conference Euram, $1^{\text {st }}-4^{\text {th }}$ June 2011, Tallin, Estonian Business School. Since then, the empirical part of the paper has been thoroughly revised, since the experiment has now taken place twice.

* Sylvain Bureau, ESCP Europe Business School, 79 avenue de la République, 75011 Paris, France \& CRG Management Research Center, Ecole Polytechnique, Paris, France, sbureau@ escpeurope.eu,

corresponding author

** Elisa Salvador, PhD in Institutions, Economics and Law (IEL), University of Turin, Italy

***Jacqueline Fendt, Chair of Entrepreneurship, ESCP Europe Business School \& CRG Management Research Center, Ecole Polytechnique, Paris, France. 


\section{Introduction}

Pivotal objectives of the Lisbon Agenda and the EU Green Paper are the promotion of entrepreneurship and the strengthening of SME activity with the aim to improve international competitiveness. These priorities are linked to education, lifelong learning and R\&D (Leppisaari\&Tenhunen, 2009).

If, according to Autio and Yli-Renko (1998: 974), "successful NTBFs ${ }^{1}$ in the Information Society could prefer to remain small and be less concerned with growth", it is also known that small firms have strengths that cannot easily be replicated by a large firm, such as entrepreneurial dynamism, internal flexibility and specialized expertise. The general autonomy propensity and strong independence attitude of SMEs (Katz, \& Green, 2006; van Gelderen et al., 2005; Miles et al., 1999; Venkataraman et al., 1990) do not help foster their growth potential. Notwithstanding, from a macroeconomic perspective, the importance of entrepreneurial ventures' growth is well acknowledged, since these are primordial for economic value and job creation. And indeed, numerous are the structures and initiatives that have recently been established for nurturing and developing young firms, including the recent phenomenon of facilitating research spin-offs (Salvador, 2009), the creation of science parks, incubators and accelerators, and multiple business plan competitions at regional and country level. Furthermore, the European Commission Communication on the role of universities in the "Europe of knowledge"(2003)fostered much attention towards flexible structures that link universities, businesses and local territory. Such facilitators include Technology Transfer Offices (TTOs) and Industrial Liaison Offices (ILOs) (O’Gorman et al., 2008; Siegel et al., 2007; Clarysse et al., 2007; Jain\&George, 2007), as well as a number of training, coaching and mentoring initiatives. But, given this context of importance of new venture creation and growth and the importance of entrepreneurship education at all levels, what can we say about the role of business schools? What are they doing and could they do more?

According to Gilbert et al. (2006: 937) "the entrepreneur must choose growth and (that) growth will occur most readily when the entrepreneur possesses the resources that enable growth, has a strategy that fosters growth, operates in an industry conducive for growth, and develops structures and sys-

\footnotetext{
${ }^{1}$ According to Hogan and Hutson (2007: 91) "New technology-based firms (NTBFs) are independent ventures less than 25 years old that supply a product or service based on the exploitation of an invention or technological innovation".
} 
tems that accommodate growth". Business schools may play a key role in helping entrepreneurs discover and understand the nature of growth, get better access to the systems that enable growth and develop a behavior conducive to their aspired growth level. But why would business schools want to do that, and is this really their job? After all, they are primarily here to prepare the new generation of business leaders, not help small business owners, often unrelated to our school, or even not graduated. The authors are business school professors and, for some years now, have noticed some deficiencies in extant, strongly individualized business curricula that still often take place in isolation from the real world. The need to practice management and entrepreneurship education in a co-constructing logic with the real world, to go beyond the classic start-up creation exercises, and to increase the exposure to real risk has been evidenced and theorized in separate publications and will not be further developed here. It is mentioned to explain that the idea for the experiment in this paper has been nourished from four sides: i) the need to expose business school students to tangible real-life situations that go beyond the romantic involvement in start-ups recently created by their predecessors, ii) the need for faculty to better understand growth and sustainable value creation, iii) the need of small business owners to grow their businesses, and iv) the need for the economy to increase the mid-size segment of entrepreneurial firms. The latter objective is especially relevant in France, where this mid-size firm segment is strongly underdeveloped, and where this experiment takes place. To our knowledge, there is a gap in the literature associated with the understanding of the described phenomena, especially regarding initiatives by business schools for the learning and promotion of small business growth. Business schools focus on large firms (Wright et al., 2007), or when they do address the entrepreneur, it is in relation with the early stage of company creation, where they may provide business plan competitions incubation and suchlike, principally for their own students and young graduates. But we purport that business schools have a lot to gain from working with small firm owners. There is much to learn from the small business growth stage, and from opening up the business school to an atypical audience. The owners in turns can create value for themselves and for the small business community around them. Also, in recent years, alternative learning approaches deserve special attention, as the business reality is changing and the challenges that are expecting B-school graduates, are increasing. Among such new learning initiatives we find many of the action learning type, i. e. seeking a closer involvement with the real 
world. Another domain is the use of the Internet (regarding e-learning but also in terms of social network theory, for knowledge co-creation and community-building) tailored to support the professional development of entrepreneurs (Green Paper, 2003). In this vein, we suggest that mixed audience entrepreneurship education programs may be relevant not only for students seeking to become entrepreneurs, but also for entrepreneurs of small businesses seeking to grow these and, last but not least, for the business school itself, be it to gain societal visibility and recognition and/or to discover new ways of fulfilling its mission. We have been on the lookout for theory and for best practices for several years before writing this inquiry. We have studied the literature and looked for innovative approaches and these endeavors have led to first pedagogic experimentations in 2010, and, in a more conceptualized manner, in 2011. This reflection and action is mirrored in this paper. Some key issues with involving different stakeholders in common training programs, besides the optimization of objectives and pay-offs, are time, money and location. With this in mind, and based on a set of prerequisites that we collected from the literature and from an overview of best practices, we started establishing pedagogic program. From it arose three major directions, in which we suggest business schools could evolve: i) regarding the schools as a whole: they can change their nature, to become less elite-oriented, less individual-centered, more open to unusual audiences, and thus value-creating in a more integrated, more holistic sense for their students and alumni and for the community and society they belong to, ii) regarding entrepreneurship education: they can strongly and regularly involve their students in business realities, and this well beyond the start-up level, into the growth/ scaling phase, and iii) they can make more systematic and sophisticated use of the Internet for growth-enhancement through elearning, and especially through community-building. These measures, as we seek to evidence, encourage effectual behavior, which in turns enhances opportunities and serendipity (DeTienne\&Chandler, 2004).

The paper is structured as follows. After an introduction we lay down the construct of small firm growth and some theory and practice of entrepreneurship education. We close this part with a multilevel table of prerequisites for learning and fostering growth in small firms (Table 1). Grounded in this knowledge we designed and ran a mixed-audience action learning experiment, which we describe in some detail. In a following section we discuss the experience and conceptualize it in an inte- 
grated process model (Figure 1). We close by developing three suggestions for the development of entrepreneurship pedagogy in contemporary business schools.

\section{Growth in early stage ventures: a multilevel challenge}

The decisive role of small businesses for the creation of employment, prosperity and innovation is well theorized, and economic development policy increasingly focuses on entrepreneurial ventures as a means of generating growth. A research field has emerged in terms of the roles and interactions of government policy, universities, and other private and public facilitators of growth and the creation and dissemination of knowledge and innovation (Clifton et al., 2010). The European Commission purports that "SMEs are the backbone of European economy (...) In most EU Member States, SMEs make up over $99 \%$ of enterprises and do generate a substantial share of GDP, are a key source of new jobs and, as well, are a breeding ground for entrepreneurship and new business ideas" (Nachira, 2002: 3). Furthermore, as underlined by Leppisaari and Tenhunen (2009: 190), promoting entrepreneurship and strengthening SME activity with the aim to improve international competitiveness are pivotal objectives of the Lisbon Agenda and the EU Green Paper, linked to education, lifelong learning and R\&D because "entrepreneurs need to update and develop their skills to keep ahead in a changing economy". Macro-economic barriers to and drivers of growth are regularly analyzed, at country and regional levels (e. g. Doern, 2009; Krasniqi, 2007) as a basis for the development of facilitating policies and infrastructures.

Beyond these macro-level considerations, growth is a complex process at firm level, especially in the early stages(Gilbert et al., 2006).With Achtenhagen et al. (2010: 289) we will define growth as "a complex phenomenon - with a strong emphasis on internal development - which differs from the simplified conceptualization of growth used in empirical studies". Indeed a lot of research projects limit growth to a simple artifact used to measure the evolution of an output. In this paper, growth is not so much related to the result than to a process of transformation which can be defined as the combination of three processes: the structuring of an expanding organization, a learning process related to an innovative project and the discovery of new resources (Silberzahn\&Midler, 2008). 
Far from being a natural dynamic, growth propensity can vary dramatically from one firm to another and the variance can sometimes be counter-intuitive (Terpstra\& Olson, 1993). For instance, many examples used to illustrate extreme growth come from such high-tech firms as Google, Facebook, E-bay. Nonetheless, high-tech companies are far from being naturally growth-oriented. Autio and Yli-Renko (1998) evidence through extensive empirical data that a majority of new technologybased firms will never be other than micro firms, because growth is not a principal goal. Indeed, a growth myopia and the absence of a rapid growth (Autio, 1997; Harrison \& Leitch, 2007) characterize the great majority of new technology-based firms. More generally, at the individual level, van Gelderen et al. (2005: 101) argue that many entrepreneurs "start out small and wish to remain so". In fact, "many small business managers deliberately refrain from exploiting opportunities to expand their firms. (...) Many small business managers are not willing to pursue growth (...) many small firms do not realize their full growth potential" (Wiklund et al. 2003: 247-248). Another key aspect to be taken into account is the autonomy propensity and strong independence attitude of SMEs (Katz, \& Green, 2006; Gilbert et al., 2006; van Gelderen et al., 2005; Miles et al., 1999) and their focus on "organizational egocentricity" (Venkataraman et al., 1990). Gilbert et al. (2006: 928) has concluded that "the most important predictors of new venture growth include the entrepreneur characteristics, resources, strategy, industry and organizational structure and systems". Given this evidence, one could assume that the interest in growth is not incentivized enough at the entrepreneurs' level. Moreover, when entrepreneurs are willing to develop their firms they must not only access financial resources but also expertise, partners, visibility and so forth (Sarasvathy, 2008). Beyond the entrepreneur's traits and its project's characteristics, the immediate environment is absolutely key for the growth propensity (Sarasvathy, 2008; Venkatesh, 2006, 2008). Because of their social and cultural backgrounds, many entrepreneurs remain trapped and cannot expand their business. The extreme example of entrepreneurs developing their business within American ghettos can illustrate these issues (Venkatesh, 2008).

In sum, research gives us some indications on how to unleash entrepreneurial mindset and growth, at all levels of analysis. Favorable economic national, regional and local conditions are all found to have a direct positive relationship upon the expansion of new businesses. At the firm-level we identify the need to have solid but adaptable organizational and operational networking capabilities 
in place, regionally and internationally (Clifton et al., 2010; Collinson \& Quinn, 2002; Danis et al., 2010). At the micro-level, the qualifications, both technical and social, and the networking capabilities of the business founders/owners and their teams, seem to be crucial (Cooke \& Wills, 1999; De Carolis \& Saparito, 2006; Garud, 1997). Last but not least, we have to recognize that the decision to grow the firm is also a difficult one. Therefore, as underlined by Gilbert et al. (2006), a limited growth does not always mean an inability to grow but a limited desire of the entrepreneur to grow the firm. The challenge lies in giving small firm entrepreneurs insight to permit them to make good choices on growth, andsupport if they choose to grow, in sometimes adverse environments.

\section{Entrepreneurship education: can growth be taught?}

The first recorded entrepreneurship class was held in 1947 at Harvard business school in the US, but only since the 1980s it emerged as a distinct field and reached serious dimensions and, more recently, remarkable success (Katz, 2003; Kuratko, 2005). The number of universities offering entrepreneurship courses grew from a handful in the late 1970s to more than 400 in 1995, and 1600 by 2005 (Katz, 2003; Rasmussen \& Sorheim, 2006; Raichaudhuri, 2005). Course rates continue to grow not only in the US, but especially in Europe and in emerging economies in Asia and Latin America. The topic is young and lacks theoretical framing, and yet it is of such growing importance (Kuratko, 2005; Raichaudhuri, 2005), that "it is already impossible to give an extensive overview of the entrepreneurship education literature" (Lobler, 2006: 21).

Surprisingly, despite the eclectic nature of the field and the wide portfolio of academic disciplines involved, almost all current programs seem to display fairly common structures and features: their curricula follow some kind of linear process that starts with an idea-finding module and ends in the writing up of a structured business plan and, usually, in the pitching of this plan before an audience made up of entrepreneurs, angel investors, and faculty (Kuratko, 2005). This key mythical document is designed to characterize and assess a situation and the prospects of an existing or future organization for its managers and stakeholders (Honig, 2004). Mostly, these plans are a core component of programs and degree exams. They contain developed ideas for the launch of new start-ups or business ideas within an existing company (Kuratko et al., 2001; Miles and Covin, 2002; Morris and Kuratko, 
2002; Zahra et al., 1999). These efforts to contextualize entrepreneurship education remain essentially predictable: temporality and expectations are perfectly known, the risks are virtually none; the students act in a safe and recognizable environment and operate within a logic where the classic formula for a "good student" largely remains valid and where a conforming and purely rational approach to problems is often the most successful route to take, and sometimes the only possible route. To "succeed", under such teaching, it is sufficient to primarily work hard in the library, to navigate the Internet intelligently and, in the best cases, to conduct a small, often very limited, market study.

While a basic set of analytical tools and methods can be taught in this manner, the entrepreneurial reality presents itself quite differently most of the time: serendipity, random encounters, the unexpected, chance, vague objectives, conflict, risk-taking, subversion, questioning the usual rules, and creativity make up most of the tales when one listens to entrepreneurs explaining their successes. This part of entrepreneurial agency, usually theorized within the construct of opportunity recognition, is scarcely addressed during the months of entrepreneurship teaching, where everything is signposted, framed, coordinated and chaperoned (Honig, 2004). Indeed, for several years now, a growing number of entrepreneurship scholars have been challenging, or at least highlighting the great volume of limitations to this "teaching by business plan" approach (Aronsson, 2004; Daly, 2001; Fayolle, 2000; Honig, 2004; Lave \& Wenger, 1991; Pittaway \& Cope, 2007a, 2007b) and some, such as Chia, demand a “...radical change in intellectual and pedagogical priorities" (1996: 410). Despite these criticisms there is evidence that, be it in start-up creation, growth or corporate venturing, entrepreneurship education can be a crucial factor in fostering entrepreneurial attitude (Gorman et al., 1997; Kourilsky\&Walstad, 1998) and enhancing performance (Okudan\&Rzasa, 2006; Fayolle, 2008). Many aspects of entrepreneurship can be taught (Garavan\&O'Cinneide, 1994; Kuratko, 2005; Raichaudhuri, 2005; Okudan, Rzasa, 2006) and there is a positive relationship between formal entrepreneurship training and venture performance (Van der Sluis et al., 2008).But given that the contexts in which entrepreneurs work, tend to be characterized by high uncertainty, over information, and consequently limited predictability of the future, entrepreneurship education should strive to account, and prepare, for that. De facto, the strong volatility leads entrepreneurs to experience ambiguity, confusion, if not 
chaos. The entrepreneurial environment is a thoroughly open system in which the number of variables is much too high to carry out predictions, or even to understand or control everything . In this environment it is extremely difficult for entrepreneurs to know what they should take into account and what they should ignore .These realities, that of entrepreneurship and of its education, are still quite different.

There are very few programs designed in the world for such profiles as small firm owners and research spin-off founders. This situation is due to the discussed discrepancy between the entrepreneurs' demands and most present business schools' offers. Sexton et al. (1997), who focused on the learning needs and wants of high growth entrepreneurs and on their preferred delivery channels, claims that "entrepreneurs prefer learning experiences that are short, to the point, content-oriented, and taught by practicing professionals". Obviously, there are immediately some simple but real constrains: how to teach entrepreneurs who are working long hours? This problem has been solved for corporate managers through executive MBA programs, but it is more complicated for small venture entrepreneurs. Moreover, there is also a question of money: business education is usually very expensive and few entrepreneurs can bear this cost as they work with very limited resources. Last but not least, do business schools have the type of hybrid faculty? Practical experience is indispensable, but a solid theoretical underpinning just as much, so as to be able to co-construct knowledge as one moves along, and conceptualize some of this often highly sophisticated non-linear knowledge.

In recent years there has been a growing interest in the research spin-off phenomenon. Research spin-offs are the most evident example of integration between industry and academia (Salvador, 2009). They are a clear example of micro firms that lack business competencies (Shane, 2004; Wright et al., 2007; Mustar et al., 2008; Salvador, 2011a) and therefore could benefit deeply from an improvement in entrepreneurship education programs. Academic spin-offs - in which the founders are often scientists and not managers - have less market knowledge and little business experience to transform their knowledge into a product for the market (Clarysse et al., 2011; Wright et al., 2004). In other words, academic spin-offs contribute to the debate on the effectiveness and need for improvement of entrepreneurial ventures growth (Salvador, 2011b). This particular kind of firms serves as a proto- 
type to the practice of learning processes and of coaching and training structures, often science parks and incubators (Salvador\&Rolfo, 2011). To encourage scientists to consider commercialization and to support them through the process many universities offer incubation and coaching facilities (O’Gorman et al., 2008). Such structures facilitate essentially technological diffusion (Siegel et al., 2007). Furthermore, since the creation of science parks in the 1980s, business incubators have become a principal tool to promote enterprise creation (Wright et al., 2007). All these structures are linked to many initiatives that emerged in recent years with the aim to foster entrepreneurial activities, such as all types of business plan competitions (Wright et al., 2007: 39-40).

While these are important developments, Wright et al. (2007: 190-191) describes how business schools are not prepared for these atypical participants. First of all, there is a gap between the available courses and the needs of entrepreneurs, because "faculty in business schools typically have expertise relating to larger firms rather than close involvement with entrepreneurial new ventures" (op. cit.). Secondly, there are often important ambiguities about purpose: “...for example, how does involvement in spin-off activities relate to promotion mechanisms that give primary emphasis to research?" (op. cit.). Thirdly, there are "...questions relating to the comparative advantage of business school ac-

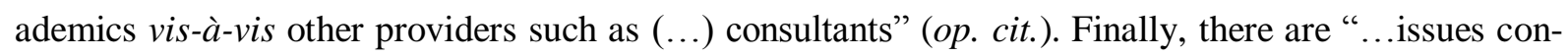
cerning the recruitment, career structure and integration of faculty in business schools whose role is to promote entrepreneurship" (op. cit.). Faculty required to contribute to the development of spin-offs and start-ups may need to have considerably more practical experience than typical business school academics".

The challenge ahead will not only be the partnership between facilitators, science parks and incubators that provide assistance to start-ups and spin-offs, but also to establish a partnership between these actors and the business school communities - i.e. essentially the business schools and their entrepreneurship activities, their networks of facilitators, business angels and venture capitalists - for training, coaching and funding the growth and scaling process. Such partnerships are not easy and are often initiated and maintained by a few passionate individuals, rather than institutional, because they often require that institutional processes and norms be trespassed (Kuratko, 2005), but they clearly 
benefit to all partners. This argument further confirms our claim that entrepreneurship education has a role to play in small business growth.

A third argument that the described need exists and is worthwhile pursuing comes from observing some recent novel education programs around the world. Rather than conceptualize these, we describe one - investigated by Akola and Heinonen (2006) - that we consider representative for education initiatives further down the value chain, as we have come to study them both practically and in the literature. This project explores the learning of entrepreneurs with training programs not only for future but also for existing entrepreneurs in five European countries (Finland, Germany, Norway, Spain, and United Kingdom). Akola and Heinonen focus on objectives, delivery methods and contents of the studied programs. The aims are to promote the start-up process of potential entrepreneurs and/or to develop the business of existing entrepreneurs. Akola and Heinonen (op.cit) evidence that in existing companies the fundamental entrepreneurial process has already taken place and the small business entrepreneur needs to focus more on managing and developing the business. The challenge, so they claim, is therefore to find suitable and effective learning contents and delivery methods for these specific circumstances, and target groups. One described UK program targeted to more mature but growth and development oriented companies ${ }^{2}$, aimed at developing the creativity, innovation and enterprise skills of entrepreneurs and/or senior managers willing to grow and their ability to achieve efficiency and growth in their businesses. The program exploited a number of different learning methods: action learning, traditional lecturing and group work, virtual learning via a web-based portal, conventional and virtual networking, and mentoring. The focus was on solving a problem or a challenge related to company growth by working together with entrepreneurs, peers and networks, mentors, facilitators and university students. These authors suggest that from the learning point of view it was important that the program be concrete and practical, because there is a need for tailor-made and tangible training programs for entrepreneurs. Moreover, personal guidance and mentoring enhance entrepreneurial learning, and smaller groups make it possible to include elements of firm interaction in the learning process. Context is also important: the content gains in meaning when integrated in a process taking

\footnotetext{
${ }^{2}$ Mastering Innovation, Creativity and Enterprise, run by the University of Salford in the North West, financed by ESF, Regional Objective 3
} 
place in a context familiar to entrepreneurs. It is thus important to take into account the delivery process, the content to be learned and the goal of a program. "It seems that learning of entrepreneurs is as a holistic and synthetic phenomenon as entrepreneurship itself, and cannot be divided into controllable elements and phases without loosing the true meaning of the word entrepreneurship" (Akola, Heinonen, 2006: 15).

To summarize this literature and best practice overview we provide a multilevel overview (Table 1) on major issues that we have identified as impacting upon SME growth, in terms of human and social capital, private and public organizational systems, and networks. This table that highlights the situated, complex and idiosyncratic nature of small firm growth and its diverse facilitating and restricting influences, served as our basic thought material upon which we constructed our pedagogic experiment. Certainly, more small firm heuristics (regarding age, size and industries) and epistemologies (regarding knowledge as an asset) and research approaches are needed to better investigate this diversity and fine-tune future programs. But we felt confident to be able to produce something useful at this stage and gain insight from it that we would not easily obtain in another form.

\section{Insert Table 1}

\section{A pedagogic experiment involving students, entrepreneurs, faculty and}

\section{facilitators}

At the moment of writing this synthesis, the authors have just terminated the second run of the pedagogic program. Inspired by the above synthesis, and by means of detailed feedbacks from all stakeholders, this program was more refined and much less improvised than the first 2010 edition. The program involved40 final year students from three top-ranking business schools or universities, mainly with a business orientation, some from engineering and design; and on the other hand 40 small business entrepreneurs from various industries. Faculty included two of the authors and a third nonacademic faculty, not involved in the research process. The challenge was to overcome some of the dichotomies between the closed linear educational system context and the non-linear, unpredictable entrepreneurial reality. We worked on three major issues. Firstly, we had to find a way to create a format able to fit into the constraints of the small business owners (i.e. limited organizational slack) to meet 
their needs (positively impact their growth performances). Secondly, as we were sourcing students from top-ranked schools in Europe, primarily France, the homogeneity and the cultural and structural conditionings of our students were strong, even if the students at hand had explicitly chosen to integrate an entrepreneurship major. Their notion of entrepreneurship is much about mythical stories. "Being my own boss" often comes with a vision of being the next Google, Facebook or suchlike, being on the front page of magazines, aligning spectacular innovations, and having a large staff doing the nitty gritty work. A more pragmatic, hands dirty understanding of the realities of entrepreneurship beyond myths and clichés was a pedagogic imperative for such a student population. Thirdly, it was necessary to go beyond a traditional linear curriculum, centered on individual learning, and obtain more collective experience of learning, full of ambiguous situations(McKelvey, 2004), chances of serendipity (Dew, 2009)and create many possibilities for participants to fail, to fail often and ever better ${ }^{3}$. We wanted to create diverse and complex social environments, propitious to a multitude of unexpected encounters, where knowledge can be negotiated and constructed socially, and where multiple realities emerge and offer their opportunities, and serendipities, to be exploited. In general, the experiment was affordable, not too time consuming but with high quality standards. We tried to create a dual - or rather multiple - learning situation; the concept was one of multi-format action learning in which we particularly aimed at fostering a sense of community and develop networks, both physical and virtual.

\section{The methodology}

For this experiment we chose a design grounded in action learning (Dick, 1997; Holcombe et al, 2009) and action research (Argyris, 1991; Dickens\&Watkins 1999;Andriessen, 2007), informed by a constructionist stance, since the observers were very much part of what was being observed, and since we aimed to increase our general understanding of a complex situation, rather than demonstrate causality. Despite the fact that we based our program on a set of prerequisites from the literature and from our own practical research, we essentially progressed less through hypotheses and deductions than through gathering rich data, from which ideas were inductively sought, as we progressed into the exer-

\footnotetext{
${ }^{3}$ This remark refers to the Samuel Beckett quote: "Ever failed. No matter. Try Again. Fail again. Fail better", in the John Gruen interview in Vogue, December 1969, page 210.
} 
cise. Contrary to entitative perspectives, which put the focus on the individual, constructionist perspectives focus on relationships (Gergen, 1995). This is appropriate both in the interaction of faculty with students on an atypical subject and in an unusual scholarly setting, and in the interaction of students with entrepreneurs in peer-to-peer pedagogic situations, and, last but not least, in the faculty - entrepreneurs interactions. In all these settings, a climate of trust needed to be developed - through interaction, understanding and sharing of values and differences, and discourse outside of group-inherent standards. Methodologically, an ethnographic approach was adopted, because of its power to develop propositions inductively by uncovering the complexities of social phenomena and recurrent patterns of relationships among underlying concepts (Rosenthal \&Rosnow, 2008). Every time, the faculty members that were not operational, undertook the observation and documentation, independently. These notes were then shared and discussed right after each learning module and inspired content and process of future modules. More than reducing units of analysis to simplest denominators we sought, at this stage, to obtain a holistic understanding of such a multi-audience experience. Despite the experimental approach and the pilot stage of the project, we claim a fair degree of academic rigor, grounded essentially in conversation and diverse triangulation practices:

- pedagogic context, content, process, and expected organizational pay-off: these were grounded in a literature analysis (Table 1);

- joint project conceptualization: the project content, objectives and process were designed and discussed together, in three phases, first between co-authors, then in class, and then by debriefing the class experience, among the co-authors and two other scholars;

- systematic observation, evidence collection and documentation: we documented the program process individually and shared notes; one or two faculty met with the students every week; every time we discussed the experience so far, asked students for feedbacks, monitored their engagement and deliverables, debriefed with them and co-constructed the forthcoming missions and tasks; and we debriefed among faculty after every step;

- triangulation: on three occasions we confronted data, observed phenomena, ethnographic notes and literature links with a fourth researcher, a sociologist who helped us organize the students and teach them basic notions of field work and event management. This confrontation with a scholar 
who was both somewhat engaged in the project and therefore familiar, but not an author, helped us visualize the contingence of the constructions of reality. He was a kind of 'interpretation enabler' and thus helped shape our options of action;

- students and participants ratings: of course we also had access to the classic end of program students and participants ratings. These were both extremely high, on average above $90 \%$ and went much beyond the ticking of boxes;

- public exposure and mirroring: since this pedagogic experiment culminated in a large-scale, multi-public event, we had access to immediate and deferred feedback from all the very different populations mentioned beforehand, and from peers and management of our own business school.

\section{The program}

We sought the same level of academic excellence and expectations as any other corporate education course, despite the imperative of openness of shortness, and of the participants' financial constraints. Three selection criteria sufficed for the entrepreneurs: their company was at least 2 years old, they had to have sales, about 150’000 Euros, and an intent to develop their firm. We did not select for academic training, industry, or innovativeness of the firms.

The communication was simple, a one-page advertisement for an entrepreneurship program on "How to grow your business?" with a short description of the program content and format (five Tuesday evenings, between 5 and 9 pm, spread over eight weeks (from mid-September to mid-November). The cost for this total training of 20 hours was purposely fixed at a very affordable 100 euros. This low price and teaching load were fixed in such a way as not to limit the access to anyone who wanted to develop his or her company. The flyer could be downloaded on the school's internet website (entrepreneurship section), and it was also sent out to our 2000-stronc community of facilitators in and around Paris, France, where the training would be held, with our encouragement to forward it. As a result, we selected 40 highly diverse entrepreneurs: aged between 20 and 60 years old, from diverse industries (e-commerce, consulting, food, textile, chemicals, banking, education...), their academic backgrounds were heterogeneous (from self-made men to $\mathrm{PhDs}$ ), and so were their cultural and social origins (entrepreneurs were mainly French, African and Asian; some from the noble quarters of Paris, 
others from difficult suburbs; the students were essentially from France, Italy, Germany, the UK, Switzerland, Eastern Europe, and Northern Africa). The companies' average annual sales reached about 1.2 million euros and they had been launched for 32 months on average. The student participants - and co-organizers, as will be explained further down - were final year master students of a leading business school and other leading universities. The principle of the program was that everyone should learn from everyone. Firstly the master students were exposed to real, "ordinary" entrepreneurs with their very real, ordinary every-day issues. These students are regularly exposed to testimonials from highly successful (usually the Internet) entrepreneurs who tell their life story and this is an important and motivating pedagogic element. But here, as for the second learning situation, the exposure was different, because these entrepreneurs came with the expectancy to learn something for their business. The master students had a superior backpack regarding methods, tools and models of management but very little practical experience, and vice versa for the entrepreneurs, even if some entrepreneurs were also graduates from prestigious schools. Thirdly, we, the organizing faculty, were interested to discover entrepreneurs - normal entrepreneurs not the highly successful ones that we usually invite in the classrooms to tell their inspiring stories. Here we are confronted with ordinary entrepreneurs that struggle every day, preoccupied by operations, impatient customers, product delays, insufficient sales, etc. and especially by bills to be paid at the end of the month. Some of them grappling with survival, others more solid but still at the beginning of their scalability they made up a perfect field of inquiry for our concepts and our teaching in the real world. Fourthly, in order to be sure to fully satisfy some of the entrepreneurs expectations that faculty was not competent to address, we invited a number of down-to-earth facilitators who had very pragmatic answers to very pragmatic questions, such as: which administration to go to for which issue, how to fill in a self-entrepreneur tax form and suchlike, which type of insurance, pension regimen, etc. is best suited for which age, project, purpose and so forth. Fifthly, we also invited a bank to bring along its small firm credit consultants, and some business angels for any equity issues and someone from the small firm subsidy organization and organized a finance consulting session. The partnership with the bank also permitted us to finance the program and the surrounding activities. 
The purpose was that the diverse participating populations and stakeholders- entrepreneurs, students, faculty, and facilitators - would earn from each other and they did, but more so, our entire school learned from this exercise to a certain extent, as these unusual external populations productively mixed with our elite student body and hundreds of entrepreneurship stakeholders flocked into school to evaluate and support their common ventures. Many a media reported on the program which was considered novel and singular, and it was, as a veritable context of knowledge co-construction and situatedness emerged, much beyond our planning and expectations. At the end, our learning experiment revealed to be "an open community-based program", from which participants walked away with newly acquired knowledge, and behaviors, but more so with tangible, value-creating collaborations with people they would have otherwise never met or sought to meet.

\section{An open community-based approach}

The program featured a diverse portfolio of pedagogic formats, methods and tools. Four sessions had a similar pattern; the fifth session took place during a huge entrepreneurial event at school with the participation of nearly 2000 entrepreneurial stakeholders from all over the country. The program participants had to organize and hold a special "event within the event" on that day. The tone was given from the first evening, that began with a precise, but very warm-hearted introduction, where course context and content were outlined, but much more than that the nature of the pedagogy: coconstruction, interactivity, iterative approach, and a willingness to leave one's comfort zone, to dare things, to fail, to let chance come one's way. A huge speed-networking was used to awaken the curiosity about each other and to allow the energy to flow from the fairly large population. Then the first two of eight lectures (twice 45 minutes during each or four evenings) were held, and a homework given, in line with the subject of the lectures. This first evening was followed by a one-hour workshop in teams of eight, roughly according to industries. Teams included students, entrepreneurs and facilitators. Faculty would circulate from team to team but more for the sake of personal interest than to monitor anything: the teams organized in an autonomous manner, with a purpose of mutual discovery of objectives and resources each one could bring to the program, and of a debrief of the lectures and the homework mission at hand. This first evening was concluded with a welcome drink and informal, unorganized 
networking. The following three modules followed a similar rhythm but they were preceded by an hour's discussion of the homework in a very small team of four (two students, two entrepreneurs). Homework was shared and general ideas and questions exchanged and discussed. Also, modules two to four contained a brief testimonial of an entrepreneur who had excelled (often by failing first) in the given lecture topic (30 minutes). All eight lectures were held in team-teaching mode with two or three faculty each time. This was motivated by faculty's interest to learn, but also because rather than segment the lectures along academic fields such as finance, logistics, marketing and so on, the modules were segmented around entrepreneurial issues, which were then treated holistically. The lectures were called "Why grow?, "How to grow?", "How to earn more and better?", "How to find, and keep, more and the right clients?" "How to internationalize?" and "How to finance growth?". Each time, a facultative homework was given. This homework, which about three quarters of the participants actually did, was discussed, as mentioned, in small team sessions at the beginning of each module, but it could also be uploaded to the collaborative platform for feedback by faculty. Home works included a review of one's business model, a client and market segmentation with detailed descriptions of niches to be addressed, a business scaling exercise, a stakeholder analysis, a growth financing strategy and the preparation of a three-minute pitch about one's business. A collaborative platform with individual and common sections served to facilitate the exchange of opinions, questions, moods and of course documents and administrative information such as dates, times, venues, etc. For the final evening the roles were divided: for the master students it meant the organization of this meanwhile reputed annual entrepreneurship event - a major element of their own degree program; for the entrepreneurs it represented an opportunity to gain in visibility, meet potential partners, get financed, find new clients and so on. They had the choice between pitching their business and resource needs before an audience of over 50 business angels, small firm bankers, facilitators, and other stakeholders, or to provide their service and or product to participate in and enhance the event organization. The great majority (30 out of 40) chose to pitch.

Based on the argument that part of any entrepreneurial success and growth lies in bringing people together and creating situations where opportunities arise and can be seized, a major purpose of this education program was to identify, hatch, scale a value-creating community of entrepreneurs and 
entrepreneur-driven stakeholders and allow them to bond. And it seemed to work. This program turned out to be a kind of perpetuum mobile of value creation: every day, new reports, acknowledgments and testimonials came in about connections that were made and that resulted in value-creating opportunities to develop, personally and at a business level. This was true for the participants and other participating stakeholders, but thanks to the integration of the program into the final event, it spread to the entire entrepreneurship community, and back. Participants of the pilot program of the prior year, came back to rejoin the new community and to share the experiences and projects that had resulted from their participation. Much of what happened was fortuitous, i.e. the program was essentially guided by the shared wish of the authors to better understand the needs and wants of "real" entrepreneurs, and to expose our essentially elite students to a contact with "normal" people, small unspectacular business owners. We developed a basic pedagogic curriculum, but included and accepted a large proportion of uncertainty, and often just let it happen. Such an approach naturally contains some advantages and limitations: on the plus side there was a relaxed curiosity and no pressure at all, i.e. whatever could be achieved was sure to be useful and welcome. On the minus side there was a lack of time and in the beginning a lack of student motivation due to an uncertainty of project prestige, of perceived purpose, and simply of due to the students' extremely heavy work load, in which this program represented only a very small part of their overall curriculum. The project was hardly listed on their curriculum; it came somewhat as a surprise to students, and was therefore essentially perceived as an additional compulsory workload at first. Moreover, it was, in a classic sense of grades and credits, very poorly credited. Of course, for the large majority of the students this perception changed very quickly as they experienced how much they could learn from these mixed sessions, by listening to these entrepreneurs, projecting themselves into their situations, proudly helping them along with some acquired methods and concepts and seeing these scholarly tools come alive. Many also, a bit later, understood the value and the power of the community that emerged from this exercise. Some evidences of this were the fact that most students went much further in their duties than required: they went to visit the entrepreneurs in their businesses, they practiced their pitches with them to help them prepare for the final night friendships developed and some even joined others' businesses, for internship and, on two occasions, as business partners. 
From these considerations we can assume that the experiential learning moment outlined above was a pedagogic experiment that served stakeholders directly, and served authors as a practical and theoretical investigation, with the goal to enhance the impact of entrepreneurship education in general, and the notion of growth within it. One important objective was to create an opportunity to our homogenous, elite student population to be exposed to "ordinary" entrepreneurs, men and women from the most diverse backgrounds that try to build a purposeful business - not necessarily high tech at all to make a living for themselves and their families, to business models, actors, processes and issues that go beyond the classical examples found in entrepreneurship textbooks and case studies. Societies are made up of social groups that have very different opinions about what is entrepreneurship and growth, and especially, what is good entrepreneurship and growth. There was an initial curiosity and a deed for tangible help that made these small business participants sign up. Even though they soon found their initial expectations somewhat shattered - this was not a course where you "consumed" knowledge, but you actually had to produce, or rather co-construct it - they very quickly understood the sense and the benefit of this approach and participated to the full. This rich exposure to the field was also briefly discussed with students, but not enough, due to the fact that their major finished soon after and many then leave the country for their international internships.

Among faculty, we came up with a broad set of findings regarding issues, actors, processes, contexts and relationships, that reaches beyond existing frameworks and theories. We summarized this pedagogic experiment in the shape of integrated process model for the teaching and learning of both entrepreneurship in general and growth as a particular notion of small business entrepreneurship (Figure 1). This model is an accurate account of the objectives, specific contexts, content elements and their combinations; behavioral changes (documented through observation and also registered from the immediate and the deferred feedback forms, as well as numerous spontaneous feedbacks), as well as the immediate and deferred pay-backs (again, these were documented right after the experiment, and they are also regularly registered. The chair of entrepreneurship keeps statistics on all entrepreneurial activities by its graduates and program participants). Also, this model tries to visualize in a simple way the iterativeness between the various elements, how the behavioral changes and the pay-offs impact the content, the objectives and the context, and so on. These learning loops must be further observed, 
because the experience of two programs is as yet insufficient, and the model must be developed in more detail and validated. In this sense, this process model is a first pit stop in our pedagogic conceptualization, but not an end. Rather would we perceive it as an invitation for discussion and feedback that will nourish future reflection, research, and experimentation: "It seems that learning of entrepreneurs is as a holistic and synthetic phenomenon as entrepreneurship itself, and cannot be divided into controllable elements and phases without loosing the true meaning of the word entrepreneurship" (Akola \&Heinonen, 2006: 15).

\section{Insert Figure 1}

We went on a search for a better understanding of small business entrepreneurs, of entrepreneurship education, especially of the education of growth. Starting from the experiment and related considerations, we close by providing some reflections and suggestions regarding small business growth and the role of business schools in its teaching. The following section shares, in some depth, three directions.

\section{Small firm growth and the business school}

Our previous academic and practical inquiries gave us some confidence that it could be purposeful to address the issue of small firm growth at a business school. Still, the unanimously positive returns on the described multi-audience pedagogic experience were unexpected. There is clearly matter here to pursue. Learning is vital for small business owners dealing with the task of stabilizing and scaling a successful firm, and the small firm growth stages are an interesting field of inquiry where many complex entrepreneurial phenomena are present, complex enough to be challenging and yet small enough to remain tangible. There is a gap in the literature associated with the nature of growth and scaling of small firms, and any specific initiatives provided by business schools in this matter. And, we believe, there is a gap between the knowledge we have about how to grow and scale businesses and the pedagogic application of this knowledge. Von Graevenitz et al. (2010) argue that the research on effects emanating from entrepreneurship education still has huge gaps and are poorly understood. It may be that little has been done in this field because we lack definitions of the "practicing entrepreneur" and also of the "venture life cycle", as well as of understanding what the entrepreneur 
needs to learn to solve the permanent transition problems that come with the growth process (Sexton et al., 1997). As Solomon explains, "from Schumpeter to today, there is a dearth of definitions, characteristics, competencies and behaviors that many believe describe the entrepreneur. Is it any wonder then, that the teaching of entrepreneurship education is fragmented with no general agreement established on whom or what are entrepreneurs or entrepreneurship? The confusion is compounded by the similarities exhibited by the small business owner manager (2006: 11)". And he adds that it may be time "...to review the entrepreneurship curricula that have evolved in the past 25 years of the new era of academic entrepreneurship (2006: 3)". But rather than wait for the 'perfect definitions' in order to act, we purport, with Sarasvathy (2008), to adopt an effectual approach and 'start with what we have'. Because as we have experienced here and tried to share as best we could: to start, to try, even imperfectly, results in such rich new knowledge about what we do, what we should and should not do, that it will bring us closer to that 'perfect definition' that our scholarly mind persists us to look for. So we shall continue to focus on initiatives toward small firm training on growth and scaling, and we encourage business schools to do so.

We suggest that such programs could develop in three main directions: i) they could change the very nature of the business school, to become less individual-centered, more open and value creating for its students and alumni and to the outside world, ii) they can strongly and regularly involve entrepreneurship students in business realities beyond the start-up level, in the growth/scaling phase, and iii) they can make systematic and sophisticated use of the Internet for growth-enhancement through elearning, and especially community-building.

\section{Changing the very nature of the business school}

The above experience encouraged us to dig deeper into effectual learning methods. For this increasingly ambiguous world that we prepare our students for, we have few clear answers at hand. Itis likely that our role as pedagogues will change. We will less and less be about transmitting knowledge, and more often about facilitating the construction of new knowledge. The complex and underresearched growth stage of small firms is an interesting field to do so. Because this early growth stage 
represents a moment of high uncertainty, of human, organizational, economic, technical, ecological and moral ambiguities and optimizations, still small enough to come close and touch the issues, but big enough to include all complexities that modern business life is made up of. It is therefore an ideal common ground on which otherwise separate populations can co-construct new knowledge and advance together: students preparing to be entrepreneurs, existing entrepreneurs from all horizons of small ventures potentially oriented toward growth, facilitators providing elements to promote that growth, and faculty seeking to understand and reconcile theory and practice, and build tangible pedagogic processes from this reconciliation. But well beyond this pedagogic field, it seems evident to the authors that our business school has clearly learned from this exercise. One immodest hypothesis is that this may not be just a fortuitous exercise of some adventurous faculty, but perhaps the beginning of a new paradigm for our elite business schools. It might be opportune to briefly describe the French - business school context in which this experiment takes place. French elite business schools recruit essentially from a two-year preparatory program managed by the Ministry of Education and culminating in a nationally ranked competition (concours national). These preparatory years are extremely rigorous, quite theoretical, and include virtually no interactional elements. They advance fundamental principles of the French educational model, such as elite thinking, excellence in abstraction and conceptualization (e.g. mathematics is the main discipline used to discriminate students during the exams), and individualization (team work is virtually non-existent). The system is grounded in meritocracy: all exams are anonymous and only the top $10 \%$ of candidates are admitted. This "Darwinist" process is self-legitimizing. The indicators used to classify students appear as absolutely objective (mathematics cannot be subjective...). Moreover, the Grandes Ecoles schools are grounded in powerful and prestigious alumni networks that facilitate members' professional careers. Finally, the status of these Grandes Ecoles (master's degree) graduates is high and has hitherto given them a considerable head start on the labor market. The logic is quite simple: the most prestigious schools harvest the best students, which are, upon graduation, in turns harvested by the best corporations for careers culminating in the best managerial positions. But this elite reality seems to be reaching its limits. In order to get access to all the creative forces necessary to cope with challenges ahead, the very elite system might in the long run to be questioned. Indeed reflections are ongoing to facilitate access through new selection 
criteria, to eliminate financial barriers early in the education process, as well as to further progress in eliminating any issues of age, cultural and social backgrounds, and to develop alternative entry modes to eliminate diploma barriers. Such changes might be needed to obtain the diversity necessary for optimal knowledge co-construction. Meanwhile, the tolerance to alterity and the introduction of other creative energies could be implemented, as we evidenced, by combining the elite student populations with other profiles in combined programs, such as the one described.

So, perhaps the time has come to open our doors much more, and more regularly, to people and organizations that are atypical for such schools. Not only to teach them, but to learn from them, just as much. Because in these atypical encounters seems to lie an important potential for societal and individual value creation. A potential that, in a complex, non-linear world may bear the necessary imagination and creativity that permits us to go well beyond what our classical, selective, homogeneous populations can achieve. Such business schools are still very much focused on the promotion of the talents of carefully selected individuals, and not enough on the quality of interactions between diverse people. But even if this hypothesis turns out to be an exaggeration, we do suggest that business schools mix with non-elite audiences and redesign their pedagogic mission in a wider sense to include more collective projects.

\section{Get students' hands dirty}

In the same vein, we propose to move out of the often stereotype silos of classical education programs and case studies and involve business school students more and more often in real life projects. Rasmussen and Sorheim (2006) evidence that to involve students in work on real business cases can act as an incentive for them to eventually start their own company. Solomon, too, expressed this necessity very clearly: "In short, there is a need to create a learning environment which mirrors the living environment within which small businesses struggle to survive and grow(2006: 27)". Without wanting to go as far as inciting students to become entrepreneurs, we purport that working on real projects develops entrepreneurial mindset, and moreover it creates real value, and permits to develop solid, large and diverse ecosystems of a wide range of stakeholders. As described earlier, large and diverse networks in turns permit fortuitous encounters, serendipity and therefore opportunity. The de- 
scribed education project is a rather far-going example, but we practice other exposures, that go less far but that permit students to get out of the classroom and work with entrepreneurs on some relevant issues, such as marketing studies, customer inquiries, due diligence processes and so forth. In many ways, such real-life immersions that we practice more and more, resemble a Swedish experience shared by Rasmussen and Sorheim. At five Swedish universities, studies are built around real innovation projects, where groups of students establish new ventures on the basis of a research-based idea, or in parallel with entrepreneurship courses. In short, programs aim both at educating entrepreneurs and at establishing new businesses: “...the focus on action-based learning and the substantial resources required for these entrepreneurship education programs may be in conflict with existing teaching practice and the university culture. The requirements of a start-up process do not fit perfectly into the timetable of university studies. Neither can the idiosyncratic learning process of starting a new venture be standardized in a course description. These challenges call for flexibility from the university management and attention towards legitimizing the initiative internally at the university (2006: 192)”. In line with this Swedish case, we suggest to introduce similar methods, for many reasons stated, such as the benefit of real value creation, network-building and exposure to real risk. More concretely, we study such models as to embed student teams on an annual basis, or for a short period - some weeks/months - in newly established enterprises, under the supervision of business school teachers. These teams would work in an internship style, i.e. not in the role of 'learning students' but of 'coconstructors'and/or of "knowledge socializers", transferring thus acquired and constructed knowledge to the start-up in order to improve the newly established firm's competencies in business and management. In this action learning mode, so we suggest, students would report during and after the internship period in order to verify their impressions and suggestions for improvement as well as the main difficulties encountered; and that the start-up teams would outline their main needs in terms of knowledge and business competence before the internship period, and evaluate the main benefits and training gaps in the end. This proposition is not so far from Wright et al. (2007: 190), who report that: "some business schools have developed links with...(facilitators) which enable MBA students, who have business experience, to get involved in a spin-off either in terms of developing business plans or in becoming part of the spin-off team. Business plan competitions are a compromise, as they help stu- 
dents to get out of the classroom but they often remain simulations of reality, at least in Europe. Still, one university in the UK has developed a module where MBA students prepare a business plan together with facilitators and academic business founders. Teams of five are assigned a piece of intellectual property (IP) and are tasked to figure out how to exploit it. Wright et al. (2007: 182-183) in the section titled "Develop compatible entrepreneurial teams with diverse commercial skills: a leading role for business schools?" suggest the following policy action for the development of academic spinoffs. "Cross-functional training courses such as MBAs with a major in entrepreneurship might be a good way of bringing people with industry experience together with those without. Business schools associated with universities that have a technical orientation could play a major role in this by adjusting their curriculum. Universities, on the other hand, could introduce scholarships for their researchers to participate in business programs. As in a business environment, the scholarship (including tuition and time) could be part of the remuneration package. Such cross-functional degree programs can also play a major role in bringing people with market opportunities together with those that spot technical solutions.

\section{Capitalizing on the Internet for e-learning and networking}

Finally, in line with what has come to be called the information and communication technology (ICT) revolution, we propose to radically professionalize the use of Internet technologies at our schools. It is a motherhood statement that information and knowledge are increasingly decisive in all domains of contemporary society. The Internet revolution (Benghozi et al., 2009) and the notion of time as a scarce resource suggest a need for "attention" in entrepreneurship education, because "a wealth of information creates a poverty of attention" (Simon, 1971, cited in Benghozi and Chamaret, 2010: 9). Furthermore, emphasis on knowledge is "a characteristic of the post-industrial world, where it is argued that knowledge will take the lead of economic resources over the traditional tangible factors such as equipment and land" (Fendt, 2005: 81). These known factors have clearly influenced and sometimes revolutionized business school teaching content. Especially the Internet, that has accelerated markets (Bruland and Mowery, 2005; Bresnahan, 2007), economic, technological, and increasingly sociocultural and political globalization processes. Fayolle (2008) reports that information and com- 
munication technologies influence entrepreneurship teaching since these technologies offers more autonomous ways of learning, outside of the classroom, often far from and beyond the traditional canons of teaching and learning. This may be so in large countries, especially developing countries, such as Latin America where we know of TEC de Monterrey and its over one million students all along the southern American hemisphere. But we do not notice this evolution much at most European business schools. But especially mixed-population programs as the one described here, could be enhanced by specific on-line programs for distance learning. Such programs could be purchased from the leaders in the field, but depending on the cultural and technical specificities of the themes could also be created by business school actors in collaboration with entrepreneurship facilitators, and could bring autonomy and flexibility to all type of learners. The potentialities remote learning tools have attracted attention in recent years in the entrepreneurship education literature. Leppisaari and Tenhunen (2009) argue that alternative learning tools are needed because of changing working life and changing skill requirements. They go further and consider even e-mentoring models applicable to entrepreneurial development. They surveyed practical development needs of entrepreneurs with the help of a questionnaire and their results indicate that e-mentoring as a learning support can actually enhance the coaching of entrepreneurs by experienced entrepreneurs. In this sense, e-mentoring can open up new opportunities of cost efficient and time and place-independent accompaniment. Examples of e-mentoring programs offered by the Association of Professional Engineers, Scientists and Managers, Australia (APESMA) and by The Mentoring Owners of Micro Business in Nottingham are evidenced to be useful support in business skills development for entrepreneurs living in remote areas and for small businesses. Hanke et al. (2005: 1) describe a pilot experiment at a State University that aims to make entrepreneurship education available to the majority of students in the US. A sample of students developed entrepreneurial skills using a unique problem-based learning approach with all course materials and grading managed on-line. The results purport that: "a problem-based, on-line approach to learn entrepreneurship is viable with significant upside potential". Kuratko (2006) recommends distancelearning technologies in a section titled: "The failure to apply technology". He describes the initiative promoted by the George Washington University with the use of the software tool "Prometheus" that integrates several multimedia options into the course. The use of case study video conferences and 
streaming are considered viable uses of educational technology for their ability to bring new live perspectives from different geographic locations (Kuratko, 2006). A similar trend regarding the use of technology in entrepreneurship education has been highlighted by Solomon et al. (2002) in their national survey on entrepreneurship education in the US.

It is thus evident that e-learning initiatives play a role when spatial, temporal and financial shortcomings represent barriers to learning, and such barriers, especially the latter two, exist even here in Europe. But the Internet can do much more than transmitting knowledge across physical, time and financial distances. As the development of open source software, of Wikipedia, and of all these highly successful social networks have evidenced, the Internet is a powerful community-builder. And, if we come back to our argumentation right through this paper, communities represent opportunities for atypical, fortuitous encounters, and for serendipity. What is more, the Internet permits the nonhierarchic development of such communities that have the advantage of serendipity, but it also permits the precise and disciplined organization of such communities and thus render lasting and sustainable the contacts among participants after the physical education experience, and/or between, and facilitates the mobilization of this community if and when a matchmaking event is opportune. So far, it is individual faculty that make use of the Internet in this form, but not so much the business schools. These, at least the leading elite schools, appear still caught between the paradigms of traditional elite selectionism and diverse co-construction of tomorrow's world.

\section{A very provisional conclusion}

"Growth is a function of the decisions entrepreneurs make about how and where they should grow their firms and the extent to which other factors are in place that enable growth to occur" (Gilbert et al., 2006: 945).In recent years the literature has theorized the growing importance of training coaching and mentoring programs for aspiring entrepreneurs with the help provided by incubator structures, science parks, business angels and business plan competitions. Simultaneously, the number of entrepreneurship education courses all over the world has risen exponentially. With this strong interest in and support for the phenomena of start-up creation and academic spin offs, we can assume that such nascent micro firms are the objects of considerable attention. And indeed, as an example, in 
France the statistics regarding company creation have tripled since the year 2000. But what about the 'growth stage', the stage where small companies must scale their value creation to the mid-size and beyond? In France, again, there is a big gap between the micro firms and the global corporations, a phenomenon that can be observed in many other European cities.

We claim that too little attention is being given to the notion of small firm growth, be it at the macro-economic level regarding its potential as a wealth and job creator, or at the firm level, in terms of the scaling techniques to deploy and the organizational adaptability they require, nor finally at the individual level, regarding the ambitions, behaviors and actions the small firm owner can and must deploy for successful growth. In consequence, we also propose that specific entrepreneurship education programs for small firm growth do have a place on the business school curriculum and, what is more, that they represent a formidable field for educational learning and experimentation and for the advancement of entrepreneurship education as a whole. To support these propositions, we have theorized the construct of small firm growth and presented state-of-the-art theories and practices of entrepreneurship education. We have then conceptualized this overview in the shape of a multilevel table of prerequisites for learning and fostering growth in small firms (Table 1). This is a very active and fastmoving research field and such an overview cannot be more than a snapshot. Still, as advocates of constructionism we used what we had, and designed and ran a pedagogic experiment, grounded in this momentary knowledge. This we have described in some detail and with all intellectual probity we have attempted to display the fortuitousness of much of its content and process. What we mean to share above all is that we see richness and concrete knowledge in this fortuitousness, and that we plan to continue to leave an important part of further programs open to allow for 'things to happen', for chance emergence and initiatives from diverse origins. We outlined this pedagogic experience in some detail, and its integrative nature, and visualized it in an integrated process model (Figure 1), to be further validated. In a last section, we reinforce why we believe the small business growth domain is worthy of attention. The entrepreneur is an important engine of economic development (Schumpeter, 1942) and, according to Casson (1982), the supply of entrepreneurs is also linked to the education system. If we want our graduates to be value-creating actors, our faculty to be effective architects and mediators between theory and practice, and if we want to help small business to grow and our econo- 
my to prosper, we can also do so by improving the context of business school education. More specifically, grounded in the presented empiry, we especially highlight three directions that kept emerging, from theory, from the experimental process and also from the diverse feedbacks of all stakeholders as the most important directions in which business schools could and should pursue their knowledge facilitation and dissemination endeavors: i) a more open, community-based business school and less elite, individual-oriented curricula, ii) student and faculty involvement in real life ventures, and iii) the professionalization of the Internet for e-learning and sustainable knowledge community building. We close by discussing these three directions and by mirroring them back to theory. This is work in progress and, we guess, our point is, that it should always be.

\section{References}

Achtenhagen L., Naldi L., and Melin L. (2010) Business growth - Do practitioners and scholarsreally talk about the samething?, Entrepreneurship: Theory \& Practice, 34(2): 289-316.

Acs, Z.J. and Audretsch, D.B. (2003)Innovation and Technological Change. inZ.J. Acs and D.B Audretscheds.

Handbook of Entrepreneurship Research pp. 55- 79, Kluwer AcademicPublishers, UK

Akola E., and Heinonen J. (2006)How to support learning of entrepreneurs? A study of training programmes for entrepreneurs in five European countries, RENT XX (Research in Entrepreneurship and Small Business), Conference Brussels, Belgium, 23-24 November 2006, 21 pages.

Andriessen, D. (2007) Combining Design-Based Research and Action Research to Test Management Solutions.Paperpresented at the Seventh World Congress on Action Learning, Action Research and Process Management, Groningen, August 22-24.

Argyris, C., and D. A. Schön. (1991) Participatory Action Research and Action Science Compared: A Commentary. In Participatory Action Research, edited by W. F. Whyte, 85-96. London: Sage.

Aronsson, M. (2004). Eduction Matters - But Does Entrepreneurship Education? Academy of Management Learning \& Education, 3(3): 289-292.

Autio, E. (1997) New, technology-basedfirms in innovation networks symplectic and generative impacts. Research Policy, 26(3): 263-281.

Autio, E., and Yli-Renko, H. (1998) New, technology-basedfirms in small open economies - An analysisbased on the Finnishexperience. Research Policy, 26(9): 973-987.

Baker, J. M. and Sinkula, W. E. (1999) The SynergeticEffect of Market Orientation and Learning Orientation on Organizational Performance. Journal of the Academy of Marketing Science, 27( 4) : 411-427.

Benghozi, P.-J., andChamaret, C. (2010)Economic Trends in Enterprise Search Solutions, JRC Scientific and Technical Reports.

Benghozi, P.-J., Bureau, S., andMassit-Folléa, F. (2009)The Internet of Things, What Challenges for Europe? Editions de la Maison des Sciences de l'Homme, Paris.

Bresnahan T. (2007)Creative Destruction in the PC Industry, in Malerba F., Brusoni S., eds., (2007), "Perspectives on Innovation", Cambridge, Cambridge UniversityPress.

Bruland K., andMowery D. C. (2005) Innovation through Time, in Fagerberg J., Mowery D. C., Nelson R.R., eds. 2005. "The Oxford Handbook of Innovation", Oxford, Oxford UniversityPress. 
Bureau, S., and Fendt J. (2011) Entrepreneurship in the Informal Economy - Why It Matters.International Journal of Entrepreneurship and Innovation, forthcoming.

Bureau, S., J. Fendt, and P. Tectin.(2011) Quand L'académisme Scientifique Remet En Cause L'académisme Pédagogique: Le Cas Des Formations En Entrepreneuriat. In Pratiques De Formation-Analyse: Former Les Managers, edited by F. Fourcade and M. Krichewsky: Université Paris 8.

Casson, M. (1982)The entrepreneur: an economic theory. Oxford: Oxford UniversityPress.

Chia, R. (1996)TeachingParadigmShifting in Management Educaton: University Business Schools and the Entrepreneurial Imagination. Journal of Management Studies, 33(4): 409-428.

Choueke, R. \& Armstrong, R. (1998) The learning organisation in small and medium-sizedenterprises: A destination or a journey?,International Journal of Entrepreneurial Behaviour\& Research, Vol. 4 Iss: 2, pp.129 140

Clarysse B., Wright M., Van de Velde E. (2011), Entrepreneurial origin, technologicalknowledge and the growth of spin-off companies, Journal of Management Studies, doi: 10.1111/j.1467-6486.2010.00991.x, forthcoming.

Clarysse B., Wright M., Lockett A., Mustar P., Knockaert M. (2007), Academic spin-offs, formal technology transfer and capital raising, Industrial and Corporate Change, vol. 16, n. 4, pp. 609-640.

Clifton, N., Keast, R., Pickernell, D., and Senior, M. (2010) Network Structure, KnowledgeGovernance, and Firm Performance: Evidence from Innovation Networks and SMEs in the UK,Growth\& Change, 41(3): 337-373.

Collinson, E., and Quinn, L. (2002) The Impact of Collaboration BetweenIndustry and Academia on SME Growth. Journal of Marketing Management, 18(3/4): 415-434.

Commission of the European Communities. (2003) The Role of the Universities in the Europe of Knowledge. communication from the Commission COM, 58 final, Brussels.

Cooke, P., and Wills, D. (1999) Small Firms, Social Capital and the Enhancement of Business Performance Through Innovation. Small Business Economics, 13(3): 219-234.

Covin, J. \&Slevin, D. (1989) Strategic Management of Small Firms in Hostile and BenignEnvironments.Strategic Management Journal 10(1): 75-87, Jan-Feb.

Covin, J.G., Green, K. M. \&Slevin, D.P. (2006) StrategicProcessEffects on the Entrepreneurial OrientationSales Growth Rate Relationship.Entrepreneurship: Theory and Practice57-81, January.

Daly, S. P. (2001) Student-Operated Internet Businesses: TrueExperiential Learning in Entrepreneurship and Retail Management. Journal of Marketing Education, 23(3): 204-216.

Danis, W. M., Chiaburu, D. S., and Lyles, M. A. (2010) The impact of managerial networking intensity and market-basedstrategies on firmgrowthduringinstitutionalupheaval: A study of small and mediumsizedenterprises in a transition economy. Journal of International Business Studies, 41(2): 287-307.

Day, J. (1998) Defining the interface: a usefulframework, in Hulbert, Day and Shaw (Eds.): Proceedings of the Academy of Marketing Symposia on the Marketing and Entrepreneurship Interface: 1996-1998, Nene UniversityCollege, Northampton.

De Carolis, D. M., and Saparito, P. (2006) Social Capital, Cognition, and Entrepreneurial Opportunities: A Theoretical Framework. Entrepreneurship: Theory and Practice, 30(1): 41-56.

De Saint-Julien, Delphine François-Philippe, (2010) Le stress des survivants à un plan social. La revue des sciences de gestion, 241.

DeTienne, D. R. \& Chandler, G. N. (2004) Opportunity Identification and Its Role in the Entrepreneurial Classroom: A Pedagogical Approach and Empirical Test. Academy of Management Learning \& Education, 3(3): 242-257.

Dew, N. (2009) Serendipity in Entrepreneurship.Organization Studies30, no. 7: 735-53.

Dew, N., Read, S., Sarasvathy, S.D.,Wiltbank, R. (2008) Outlines of a behavioral theory of the entrepreneurial firm.Journal of Economic Behavior \& Organization, April, Vol. 66 Issue 1, p37-59

Dick, B. (1997) "Action Learning and Action Research." no. 3, http://www.scu.edu.au/schools/gcm/ar/arp/actlearn.html. 
Dickens, L., and K. E. Watkins. (1999) "Action Research: Rethinking Lewin." Management Learning 30(2): 127-40.

Dixit, A.,KumarPandey, A. (2011) SMEs and EconomicGrowth in India: CointegrationAnalysis.Journal of Financial Economics, June, Vol. 9 Issue 2, p41-59

Doern, R. (2009) InvestigatingBarriers to SME Growth an Development in Transition Environments: A Critique and Suggestions for Developing the Methodology. International Small Business Journal, 27(3): 275-305.

Ensley, M.D., Pearce, C.L. \&Hmieleski, K.M. (2006) The moderatingeffect of environmentaldynamism on the relationshipbetween entrepreneur leadership behavior and new venture performance, Journal of Business Venturing, 21 (2), pp. 243-263.

Fayolle A. (2000) Exploratory Study to Assess the Effects of Entrepreneurship Programs on French Student Entrepreneurial Behaviors. Journal of Enterprising Culture, 8(2): 169-184.

Fayolle A. (2008) Entrepreneurship education at a crossroads: towards a more mature teachingfield, Journal of Enterprising Culture, 16(4): 325-337.

Fendt, J. (2005) The CEO in Post-merger Situations. An Emerging Theory on the Management of ;ultipleRealities. Delft, The Netherlands: Eburon.

Fendt, J. and Bureau, S. (2011 a). Entrepreneurship and Situationism: A Détournement. EGOS Colloquium, Gothenburg, July $201 \mathrm{I}$.

Fendt, J., and Bureau, S. (2011 b) Entrepreneurial Mindset and Informal Entrepreneurship - The Power of "Grey" : An Educational Field Experiment in the Suburbs of Paris. Harvard Business Review (Poland) (in print).

Freeman, J., Carroll, G. R. and Hannan, M. T. (1983) The Liability of Newness: Age Dependence in OrganizationalDeath Rates. American Sociological Review, 48: 692-710.

Garavan, T. N., and O'Cinneide, B. (1994) Entrepreneurship education and training programs: a review and evaluation-Part 1. Journal of European Industrial Training, 18(8): 3-12.

Garud, R. (1997) On the distinction between know-how, know-why, and know-what. Advances in Strategic Management, 14: 81-101.

Gergen, K. J. (1995) Relational Theory and the Discourses of Power. In Management and Organization: Relational Alternatives to Individualism, edited by D. M. Hosking, H. P. Dachler and K. J. Gergen. Avebury: Aldershot.

Gilbert, B. A., McDougall, P. P., Audretsch, D. B. (2006) New venture growth: a review and extension,Journal of Management,32(6): 926-950.

Golovko, E., \&Valentini, G. (2011) 'Exploring the complementaritybetween innovation and export for SMEsgrowth', Journal of International Business Studies, 42(3), 362-380

Goodson, J.R., McGee, G.W., and Cashman, J.F. (1989) Situational leadership theory: a test of leadership prescriptions. Group undOrgaznization Studies, 14.446-461.

Gorman, G., Hanlon, D., and King, W. (1997) Some research perspectives on entrepreneurship education and education for small business management: a ten-yearliterature review. International Small Business Journal, 15(3): 56-77.

Green Paper (2003) Entrepreneurship in Europe, Commission of European Communities, Brussels.

Hanke R., Kisenwether E., and Warren A. (2005) A scalableproblem-basedlearning system for entrepreneurship education, Academy of Management Best ConferencePaper.

Harrison R. T., andLeitch C. M. (2007) Dynamics of university spin-out companies: entrepreneurial ventures or technologylifestyle businesses?, in Clarysse B., Roure J., Schamp T. (2007), eds., "Entrepreneurship and the Financial Community. Starting up and growing new businesses", Cheltenham UK, Edward Elgar.

Hogan T., and Hutson E. (2007) Whatfactorsdetermine the use of venture capital? Evidence from the Irish software sector, in Clarysse B., Roure J., Schamp T. (2007), eds., "Entrepreneurship and the Financial Community. Starting up and growing new businesses", Cheltenham UK, Edward Elgar.

Holcombe, T., Ireland, R. D., Holmes Jr., R. M., \& Hitt, M. A. (2009) Architecture of Entrepreneurial Learning: Exploring the Link AmongHeuristics, Knowledge, and Action. Entrepreneurship: Theory and Practice, 33(1): 167-192. 
Holt, R. \& Macpherson, A. (2010) Sensemaking, rhetoric and the sociallycompetent entrepreneur.International Small Business Journal, 28(1), 20-42.

Honig, B. (2004) Entrepreneurship Education: Toward a Model of Contingency-Based Business Planning. Academy of Management Learning \& Education, 3(3): 258-273.

Ireland, R. D., M. A. Hitt, and D.G. Simon. (2003) A Model of Strategic Entrepreneurship: The Construct and Its Dimensions.Journal of Management 29, no. 6: 963-89.

Jain S., and George G. (2007), Technology transfer offices and institutional entrepreneurs: the case of Wisconsin Alumni Research Foundation and human embryonic stem cells, Industrial and Corporate Change, vol. 16, n. 4, pp. 535-568.

Katz J. A., and Green R. (2006) Entrepreneurial Small Business,McGraw-Hill Companies.

Katz, J. A. (2003) The chronology and intellectualtrajectory of American entrepreneurship education, 18761999. Journal of Business Venturing, 18: 283-300.

Kourilsky, M. L., and Walstad, W. B. (1998) Entrepreneurship and femaleyouth: knowledge, attitudes, genderdifferences and educational practices. Journal of Business Venturing, 13(1): 77-88.

Krasniqi, B. A. (2007) Barriers to Entrepreneurship and SME Growth in Transition: The Case of Kosova. Journal of Developmental Entrepreneurship, 12(1): 71-94.

Kuratko D. F. (2006) Entrepreneurship education: emerging trends and challenges for the 21st century, Coleman Foundation White PaperSeries for the US Association of Small Business \& Entrepreneurship.

Kuratko, D. F. (2005) The emergence of entrepreneurship education: development, trends and challenges. Entrepreneurship Theory and Practice, September: 577-597.

Kuratko, D. F., Ireland, R. D., and Hornsby, J. S. (2001) ImprovingFirm Performance Through Entrepreneurial Actions: Acordia's Corporate Entrepreneurship Strategy. Academy of Management Executive, 15(4): 6071.

Lave, J., and Wenger, E. (1991) Situated Learning: LegitimatePeripheral Participation. Cambridge: Cambridge UniversityPress.

Leppisaari I., andTenhunen M.-L. (2009) Searching for e-mentoring practices for SME staff development, Serv. Bus., 3: 189-207, DOI 10.1007/s11628-008-0060-4.

Lobler, H. (2006) Learning entrepreneurship from a constructivist perspective. TechnologyAnalysis\&Strategic Management, 18(1): 19-38.

Lumpkin, G. T., and B. B. Lichtenstein. (2005) The Role of Organizational Learning in the OpportunityRecognition Process.Journal of Business Venturing29, no. 4: 451-72.

Macpherson, A., Jones, O. and Zhang, M. (2005) Virtual reality and innovation networks: opportunity exploitation in dynamicSMEs. International Journal of Technology Management ,30(1/2),pp.49-66

Marcoulides, G. and Heck, R.H. (1993) Organizational Culture and Performance: Proposing and Testing a Model, Organizational Science, 4(2) : 209-223.

Marlow, S. (1998) So Much Opportunity - So LittleTake up : The Case of Training in Small Firms. Small Business and Enterprise Development 5 (1) : 38-47

McKelvey, B. (2004) Toward a Complexity Science of Entrepreneurship. Journal of Business Venturing, 19(3): 313-342.

Mehra, K. \&Dhawan, S. K., (2003) Study of the process of organizationallearning in software firms in India. Technovation, 23:121-129.

Miles G., Preece S. B., andBaetz M. C. (1999) Dangers of dependence: the impact of strategic alliance use by smalltechnology-basedfirms, Journal of Small Business Management, April: 20-29.

Miles, M. P., and Covin, J. G. (2002) Exploring the Practice of Corporate Venturing: Some Common Forms and TheirOrganizational Implications. Entrepreneurship: Theory and Practice, 23(3): 21-40.

Morris, M. H., and Kuratko, D. F. (2002) Corporate Entrepreneurship. Mason: South-Western CollegePublishers. 
Mustar P. Wright M., Clarysse B. (2008), University spin-off firms: lessonsfromtenyears of experience in Europe, Science and Public Policy, vol. 35, n. 2, pp. 67-80.

Nachira F. (2002)Towards a network of digital business ecosystemsfostering the local development, European Commission, Discussion Paper.

Nunes, P. M., Serrasqueiro, Z., \&Leitão, J. (2012). Is there a linearrelationshipbetween R\&D intensity and growth? Empiricalevidence of non-high-tech vs. high-tech SMEs. Research Policy, 41, 36- 53. doi:10.1016/j.respol.2011.08.011

O’Gorman C., Byrne O., andPandya D. (2008) How scientists commercialise new knowledge via entrepreneurship, Journal of Technology Transfer, 33: 23-43.

Okudan, G. E., andRzasa, S. E. (2006) A project-basedapproach to entrepreneurial leadership education. Technovation, 26: 195-210.

Pittaway, L., and Cope, J. (2007a) Entrepreneurship Education: A Systematic Review of the Evidence. International Small Business Journal, 25(5): 497-510.

Pittaway, L., and Cope, J. (2007b)Simulating Entrepreneurial Learning: IntegratingExperiential and Collaborative Approaches to Learning. Management Learning, 38(2): 211-233.

Platt, L. and Wilson, G. (1999) TechnologyDevelopment and the Poor/Marginalised: Context, Intervention, and Participation, Technovation 19 : 393-401.

Raichaudhuri, A. (2005) Issues in entrepreneurship education. Decision, 32(2): 73-84.

Rasmussen, E., and Sorheim, R. (2006) Action-based entrepreneurship education. Technovation, 26: 185-194.

Rosenthal, R., and Rosnow, R. L. (2008) Essentials of behavioral research: Methods and data analysis (3rd ed.). New York: McGraw Hill.

Salvador E. (2009), Evolution of Italian universities'rules for spin-offs: the usefulness of formal regulations, Industry\&Higher Education, vol. 23, n. 6, pp. 445-462.

Salvador E. (2011a) Are science parks and incubators good "brand names" for spin-offs? The case-study of Turin, Journal of Technology Transfer, ISSN $0892-9912$ (Print) 1573-7047 (Online), DOI 10.1007/s10961010-9152-0, 36(2): 203-232.

Salvador E. (2011b), How effective are research spin-off firmsin Italy?, Revue d'Économie Industrielle, n. 133, 1er trimestre, ISSN 0154-3229, pp. 99-122.

Salvador E., Rolfo S. (2011), Are incubators and science parks effective for research spin-offs? Evidence fromItaly, Science and Public Policy, DOI: 10.3152/016502611X12849792159191, vol. 38, n. 3, pp. 170184.

Sarasvathy, S. D. (2001) Causation and Effectuation: Toward a Theoretical Shift fromEconomicInevitabilityto Entrepreneurial Contingency.Academy of Management Review 26: 243-63.

Sarasvathy, S. D. (2008) Effectuation.Elements of Entrepreneurial Expertise.Northampton, MA: Edward Elgar.

Sarasvathy, S. D. (2004) Making It Happen: Beyond Theories of the Firm to Theories of Firm Design.Entrepreneurship: Theory \& Practice 28, no. 519-531

Schumpeter, J. (1942) Capitalism, Socialism, and Democracy. New York : HarperCollins.

Sexton D. L., Upton N. B., Wacholtz L. E., and McDougall P. P. (1997) Learning needs of growth-oriented entrepreneurs, Journal of Business Venturing, $12: 1-8$.

Shane, S. (2004), Academic Entrepreneurship. UniversitySpinoffs and WealthCreation, Cheltenham, UK, Edward Elgar.

Shane, S., and S. Venkataraman.(2000) The Promise of Entrepreneurship as a Field of Research. Academy of Management Review 25, no. 1: 217-26.

Siegel D. S., Wright M., andLockett A. (2007) The rise of entrepreneurial activity at universities: organizational and societal implications, Industrial and Corporate Change, 16(4): 489-504.

Sikka, P. (1999) Maxwell auditors and self-regulation: the verdict, European Accounting Focus, March, 13-15. 
Silberzahn, P. \& Midler, C. (2008) Managing robust development process for high-tech start-ups through multiproject learning. The case of two European start-ups. International Journal of Project Management, 19(3): 407420.

Solomon G. T. (2006) Are we teachingsmall business management to entrepreneurs and entrepreneurship to small business managers?, USASBE White PaperSeries.

Solomon G. T., Duffy S., andTarabishy A. (2002) The state of entrepreneurship education in the United States: a nationwidesurvey and analysis, International Journal of Entrepreneurship Education, 1(1): 65-86.

Stokes, D.R. (2000) Entrepreneurial marketing: a conceptualisation from qualitative research, Qualitative Market Research: An International Journal, Vol. 3, No.1, pp.47-54.

Terpstra D. E., and Olson P. D. (1993) Entrepreneurial start-up and growth: a classification of problems, Entrepreneurship: Theory and Practice, Spring: 5-19.

Thorpe, Richard; Holt, Robin; Macpherson, Allan; Pittaway, Luke. (2005) Usingknowledgewithinsmall and medium-sizedfirms: A systematic review of the evidence.International Journal of Management Reviews, December, Vol. 7 Issue 4, p257-281

Van der Sluis, J., and Van Praag, M. (2008) Education and entrepreneurship selection and performance: a review of the empiricalliterature. Journal of EconomicSurveys, 22(5): 795-841.

van Gelderen M., van der Sluis L., and Jansen P. (2005) Learning opportunities and learningbehaviours of small business starters: relations with goal achievement, skilldevelopment and satisfaction, Small Business Economics, 25 : 97-108.

Venkataraman S., Van de Ven A. H., Buckeye J., and Hudson R. (1990) Starting up a turbulent environment: a process model of failureamongfirms with highcustomerdependence, Journal of Business Venturing, 5(5): 277-297.

Venkatesh, S. (2006) Off the Books: The Underground Economy of the Urban Poor. Cambridge, MA: Harvard Business Press.

Venkatesh, S. (2008) Gang Leader for a Day.A Rogue Sociologist Takes to the Streets. New-York: Penguin.

Von Graevenitz G., Harhoff D., and Weber R. (2010) The effects of entrepreneurship education, Journal of Economic Behavior \& Organization, 76 : 90-112.

Wang, Y \&Poutziouris, P. (2010) Entrepreneurial risktaking: Empiricalevidencefrom UK familyfirms

Wiklund J., Davidsson P., andDelmar F. (2003)What do theythink and feel about growth ? An expectancy-value approach to small business managers'attitudestowardgrowth, Entrepreneurship : Theory and Practice, Spring : 247-270.

Wiklund, J. (1999) The sustainability of the entrepreneurial orientation -- performance relationship. Entrepreneurship Theory and Practice(Fall), 37-48.

Wiklund, J., \& Shepherd, D. (2005) Entrepreneurial orientation and small business performance: a configurationalapproach. Journal of Business Venturing.20(1), 71-89.

Wiklund, J., and D. A. Shepherd. (2003) Aspiring for, and Achieving Growth: The Moderating Role of Resources and Opportunities.Journal of Management Studies40, no. 8: 1919-41.

Wolff, J. A. \&Pett, T. L. (2007) Learning and smallfirmgrowth : The role of entrepreneurial orientation. Academy of Management Conference Best PaperProceedings

Wright, M., Clarysse, B., Mustar, P., and Lockett, A. (2007) Academic Entrepreneurship in Europe, Cheltenham UK, Edward Elgar.

Wright, M., Vohora, A. et Lockett, A. (2004), The Formation of High-Tech UniversitySpinouts: The Role of Joint Ventures and Venture Capital Investors, Journal of Technology Transfer, vol. 29, n. 3-4, pp. 287310.

Zahra, S. \& Covin, J. (1993) Business Strategy, Technology Policy and Firm Performance. Strategic Management Journal.14, 451-478

Zahra, S. \& Covin, J. (1995) Contextual Influences on the Corporate Entrepreneurship-Company Performance Relationship in EstablishedFirms : A Longitudinal Analysis. Journal of Business Venturing, 10(1), 43-58.

Zahra, S. A, George, G. \&Dharwadkar, R. (2001) Entrepreneurship in the multinational corporation: the effects 
of corporate and local contexts. Academy of Management Proceedings, pp. G1-6

Zahra, S. A., J. Hayton, J. Marcel, and H. O'Neill. (2001) Fostering Entrepreneurship During International Expansion: Managing Key Challenges. European Management Journal, 19, no. 4: 359-69.

Zahra, S. A., Kuratko, D. F., and Jennings, J. E. (1999) Corporate Entrepreneurship and WealthCreation. Entrepreneurship:

Theory

and

Practice,

25(1):

44-50. 
TABLE 1: Selected scholarly voices on issues impacting upon SME growth at all levels

\begin{tabular}{|c|c|c|}
\hline (Mainly) macro-level & (Mainly) firm-level & (Mainly) individual level \\
\hline $\begin{array}{l}\text { SMEs are primary wealth and job creators (Nachi- } \\
\text { ra, 2002) }\end{array}$ & $\begin{array}{l}\text { Collaboration between academia and } \\
\text { firms favors growth (Collinson\& Quinn, } \\
\text { 2002) }\end{array}$ & $\begin{array}{l}\text { Learning processes related to innovation favor } \\
\text { growth (Silberzahn\& Midler, 2008) }\end{array}$ \\
\hline Bureaucracy as a barrier to growth (Krasniqi, 2007) & $\begin{array}{l}\text { Growth performance is related to efficient } \\
\text { access to resources (Sarasvathy, 2008) }\end{array}$ & $\begin{array}{l}\text { Entrepreneurs prefer to stay small (Van Gelder } \\
\text { et al. 2005); growth myopia (Autio, 1997) }\end{array}$ \\
\hline $\begin{array}{l}\text { R\&D intensity restricts growth of small firms and } \\
\text { non-hightech firms (Nunes, Serrasqueiro\&Leitao, } \\
\text { 2012) }\end{array}$ & $\begin{array}{l}\text { Capacity to permanently adapt structure } \\
\text { of growing firm (Silberzahn\& Midler, } \\
\text { 2008) }\end{array}$ & $\begin{array}{l}\text { Pro-activeness, risk-taking, innovative behav- } \\
\text { iors (Wiklund\& Shepherd, 2003, 2005) }\end{array}$ \\
\hline $\begin{array}{l}\text { Innovation and export positively reinforce each } \\
\text { other (Golovko\&Valentini, 2011) }\end{array}$ & $\begin{array}{l}\text { Balance firm management and personal } \\
\text { goals (Wang \&Poutziouris, 2010) }\end{array}$ & $\begin{array}{l}\text { Need to overcome barriers from social and cul- } \\
\text { tural origins (Venkatesh, 2008) }\end{array}$ \\
\hline $\begin{array}{l}\text { Positive causality between SME output/growth and } \\
\text { national GDP (Dixit \& Kumar Pandey, 2011) }\end{array}$ & $\begin{array}{l}\text { Participative, transformational leadership } \\
\text { style impacts positively on small firm } \\
\text { growth (Ensley et al, 2006) }\end{array}$ & $\begin{array}{l}\text { Networking capabilities are indispensable for } \\
\text { SME growth (De Carolis\&Saparito, 2006) }\end{array}$ \\
\hline $\begin{array}{l}\text { Policy initiatives can support SME learning and } \\
\text { network development, but best so when done indi- } \\
\text { rectly, through intermediaries (Mehra\&Dhawan, } \\
\text { 2003; Thorpe et al, 2005) }\end{array}$ & $\begin{array}{l}\text { Dynamic capability, s.a. inter-firm rela- } \\
\text { tionship-building; structure and routine- } \\
\text { building focused on opportunity recogni- } \\
\text { tion (Mcpherson, Jones \& Zhang, 2005) }\end{array}$ & $\begin{array}{l}\text { Collaborative sensemaking, rhetoric and social } \\
\text { competence are decisive for SME growth (Holt } \\
\& \text { Macpherson, 2010) }\end{array}$ \\
\hline $\begin{array}{l}\text { Opportunity recognition is related to growth and to } \\
\text { societal, organizational and individual learning } \\
\text { (Covin \&Slevin, 1989; Covin et al, 2006; Ireland \& } \\
\text { Hitt, 2003; Wiklund\& Shepard, 2003) }\end{array}$ & $\begin{array}{l}\text { Small firm resource constraints } \\
\text { (Acs\&Audretsch, 2003), can be counter- } \\
\text { acted by development of values and be- } \\
\text { haviors and help adapt to liabilities of } \\
\text { smallness (Freeman, Carroll \&Hannan, } \\
\text { 1983) within business environment } \\
\text { (Wolff \&Pett, 2007) }\end{array}$ & $\begin{array}{l}\text { Fostering of leadership along entrepreneurial } \\
\text { attitudes e.g. coping, helps overcome growth- } \\
\text { inhibiting stress, crises, and dichotomies (De } \\
\text { Saint-Julien, 2010) }\end{array}$ \\
\hline $\begin{array}{l}\text { Small business hubs help favor performance } \\
\text { through inter-business cooperation, exchange en- } \\
\text { trepreneurial scenarios and better comprehend } \\
\text { small business administration (Wang \&Poutziouris, } \\
\text { 2010) }\end{array}$ & $\begin{array}{l}\text { A combination of effectual and causal } \\
\text { logics create organizational contexts in } \\
\text { which growth can thrive (Dew et al, } \\
\text { 2008; Sarasvathy, 2001; Bureau \& Fendt, } \\
\text { 2011) }\end{array}$ & $\begin{array}{l}\text { To provide growth-related knowledge one must } \\
\text { understand how the entrepreneur makes sense } \\
\text { of situated realities, often living the business as } \\
\text { an extension of the self, rather than a vehicle to } \\
\text { realize profit (Thorpe et al, 2005) }\end{array}$ \\
\hline $\begin{array}{l}\text { Learning/advice structures for SMEs must be sensi- } \\
\text { tive to the entrepreneurs' capabilities, experience } \\
\text { and identity, and to his/her context and the activity } \\
\text { in which they are embedded and engaged (Thorpe } \\
\text { et al, 2005) }\end{array}$ & $\begin{array}{l}\text { Learning contexts for SME performance } \\
\text { move away from classroom teaching to } \\
\text { action (Kirby, 2004); paradigm change; a } \\
\text { "radical change in intellectual and peda- } \\
\text { gogic priorities" (Chia, 1996) }\end{array}$ & $\begin{array}{l}\text { Entrepreneurial learning must move away from } \\
\text { classical equilibrium-based, linear understand- } \\
\text { ings, to creative, effectual approaches, to draw } \\
\text { from broad ranges of relevant and seemingly } \\
\text { irrelevant perspectives and sources, to allow } \\
\text { for serendipity (Bureau \& Fendt, 2011; } \\
\text { Fendt\&Bureau } 2011 \text { a, } 2011 \text { b; Bureau } \text { et al., } \\
\text { 2011) }\end{array}$ \\
\hline $\begin{array}{l}\text { Government's role is best to support networking } \\
\text { activities and general architecture, but not to be di- } \\
\text { rectly involved in its delivery (Pittaway et al, 2004) }\end{array}$ & \multicolumn{2}{|c|}{$\begin{array}{l}\text { Learning for entrepreneurs must be concrete and tangible..., mixed audiences work well; } \\
\text { virtual learning; networking both physical and virtual are essential (Akola \&Heinonen, } \\
\text { 2006) }\end{array}$} \\
\hline
\end{tabular}




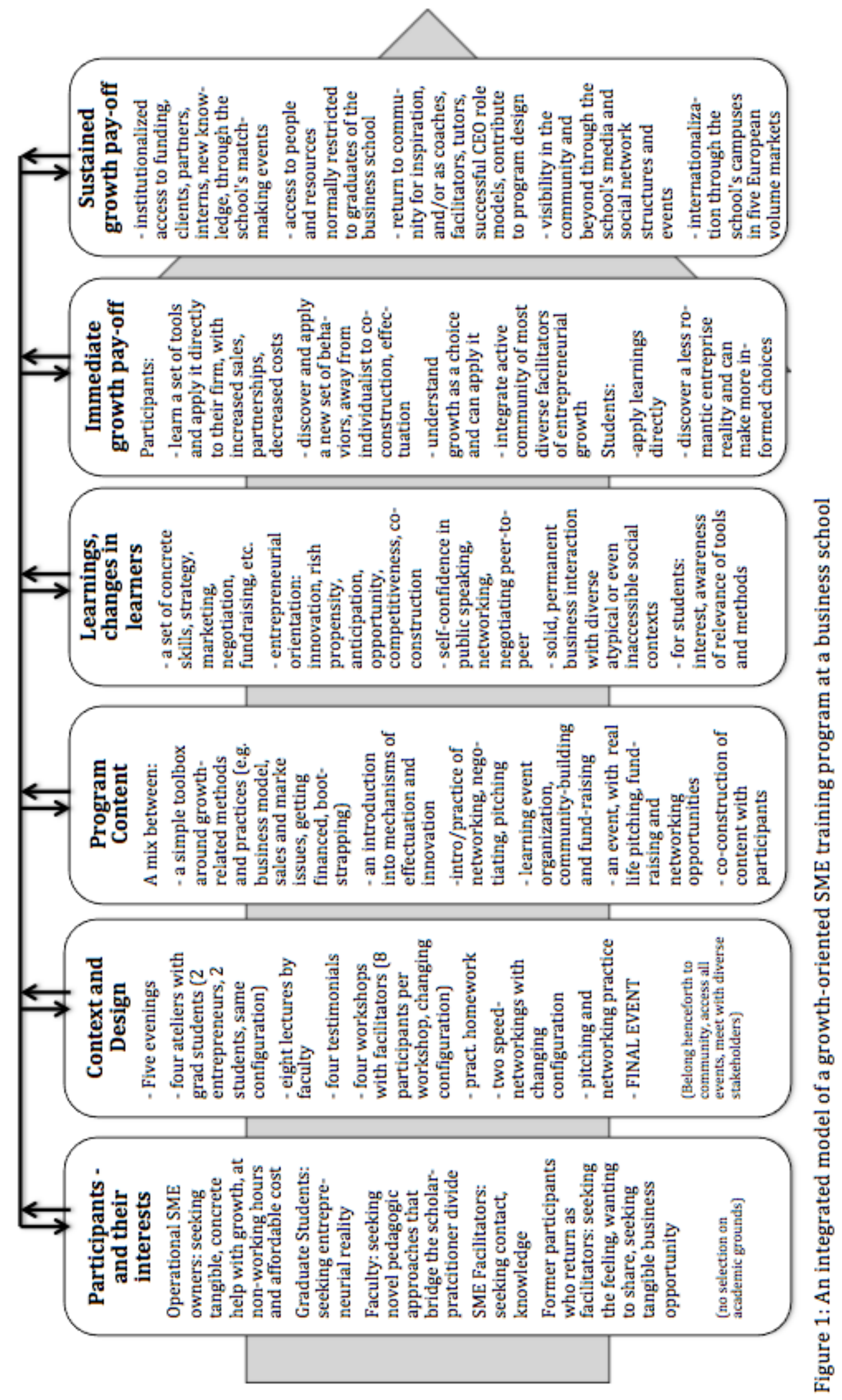

